\author{
Review Article \\ www.ijrap.net
}

\title{
SIGNIFICANCE OF NATURAL SLEEP AND EFFECT OF SLEEP DEPRIVATION ON HEALTH:
}

\author{
A REVIEW \\ Suramya Suresh ${ }^{* 1}$, Akhilesh Shukla ${ }^{2}$, Haroon Irshad ${ }^{3}$, Leena P Nair ${ }^{3}$, Jaya Shankar Mund ${ }^{4}$ \\ ${ }^{1}$ PG Scholar, Department of Ayurveda Samhita, Sanskrit and Siddhanta, Amrita School of Ayurveda, \\ Vallickavu, Clappana P.O. Kollam, Kerala, India \\ ${ }^{2}$ Lecturer, Govt. Ayurveda College, Bilaspur, Chhattisgarh, India \\ ${ }^{3}$ Assistant Professor, Department of Ayurveda Samhita, Sanskrit and Siddhanta, Amrita School of Ayurveda, \\ Vallickavu, Clappana P.O. Kollam, Kerala, India \\ ${ }^{4}$ Professor and H.O.D, Department of Ayurveda Samhita, Sanskrit and Siddhanta, Amrita School of Ayurveda, \\ Vallickavu, Clappana P.O. Kollam, Kerala, India
}

Received on: 24/06/16 Revised on: 25/07/16 Accepted on: 01/08/16

\begin{abstract}
*Corresponding author
E-mail: drsuramyasuresh@gmail.com
\end{abstract}

DOI: $10.7897 / 2277-4343.074153$

\section{ABSTRACT}

Sleep is essential for our well being and occupies about one third of our lifespan. Sleep affects how we await, feel and perform on a daily basis, which have a major shock on our overall quality of liveliness. Getting enough quality sleep at the right times can protect our physical and mental health, quality of life, and safety. The way we feel while we are awake depends in part on what happens while we were sleeping. The constructive effects of natural sleep have been very deeply considered and interpreted by both Ayurvedic classics and innovative researches. Certain people had considered sleep as a mere "break down" time when our brain takes a rest. But recent researches show a very clear connection between proper sleep and well being of a person. Some of the medical conditions like diabetes, obesity and cardiovascular disease, etc. develop over long periods of time due to sleep loss. The present article is aimed to highlight the significance of proper sleep and effect of sleep deprivation on health in the view of Ayurveda and contemporary science.

KEY WORDS: Nidra, Sleep Deprivation, sleep pattern.

\section{INTRODUCTION}

Sleep is a basic human need and is essential for good health, quality of life and performing well during the day ${ }^{1}$. The importance of sleep in our life can be realised by the time human beings spend sleeping. It is an important physiological function of the body which occupies almost $1 / 3^{\text {rd }}$ of our lifespan $^{2}$. The constructive effects of natural sleep have been very deeply studied and understood by both Ayurvedic classics and modern researches. Certain people had considered sleep as a mere "break down" time when our brain takes a rest. Due to busy work schedule people try to trim down their sleeping hours in order to find more time to read, work etc. They are unaware about the long term health issues which can take place due to improper and inadequate sleep. But recent researches have shown a very strong association between proper sleep and well being of a person. Some of the medical conditions like diabetes, obesity and cardiovascular disease, etc. develop over long periods of time due to sleep deprivation.

\section{Physiological effect of natural sleep}

Sleeping is essential for us to live a balanced life ${ }^{3}$. Sleep is a natural way of restoring our physical and mental vitality and plays a vital role in good health and well-being throughout our life. It is a complex and essential function of our life. Since 1950 s, there is continuous research in the fields of neurology, neuroscience, psychiatry, anatomy, and physiology, etc., to understand the biological process of sleep and its effect on various systems of the body ${ }^{4}$. In Ayurveda, sleep naturally occurring at night is considered as Bhootadhatri (mother who protects and nourishes the person) ${ }^{5}$. A number of vital physiological changes occur during sleep and help people stay healthy and function at their best ${ }^{6}$. Good quality sleep during night removes drowsiness and restores the natural equilibrium of the body tissue ${ }^{7}$. When a person is asleep the muscles in his body relaxes thereby ${ }^{8}$ helps to repair the wear and tear of cells and tissues occurring during our day to day life ${ }^{9}$. For better knowledge and learning good sleep is very essential ${ }^{10}$. Researches have proved that a good sleep at night can improve learning. A person having a good night's sleep can grasp well than a sleep deprived person. Good night sleep helps in memorizing the things which we studied earlier. It helps in improving creativity. It also helps in a clearer thinking ${ }^{11}$. Proper nourishment of the body and strength depends upon the adequate sleep during night ${ }^{12}$. Studies have proved that being well rested improves the body's responses to infection, which protect us from onslaught of diseases ${ }^{13}$. Proper sleep even enhances longevity in humans ${ }^{14}$ and there are enough evidences available that both short sleepers and long sleepers are at an increased risk of all causes of mortality ${ }^{15}$. The benefits of proper sleep as described in different classics is given in the Table $1^{16-}$ 20 . 
Suramya Suresh et al / Int. J. Res. Ayurveda Pharm. 7(Suppl 3), Jul - Aug 2016

Table 1: Merits of healthy sleep as described in Ayurvedic classics

\begin{tabular}{|c|c|c|}
\hline $\begin{array}{c}\text { Charaka Samhita/ Astanga } \\
\text { samgraha }\end{array}$ & Sushruta Samhita & Bhavaprakasha / Yogaratnakara \\
\hline Bala (Strength) & Aroga (Free from disease) & Dhatusamyam (Balance of bodily tissue) \\
\hline Jnana (Knowledge) & Sumanasya (Pleasant mind) & Atandra(Free from drowsiness) \\
\hline Paste (Growth) & Varna (color/complexion) & Pusti(Nourishment) \\
\hline Sukha (Happiness) & Bala (Strength) & Varna (Complexion) \\
\hline Vrishata (Virility) & Vrishata (Virility) & Utsaha (Enthusiasm) \\
\hline Jeevitham (Long span) & Natisthoolakrisha (Well built body) & Agnideepti (Digestion) \\
\hline & Shatayu(100 years of life) & \\
\hline
\end{tabular}

\section{Natural sleep pattern for healthy living}

Ayurveda regards Nidra as one of the most essential factors responsible for a healthy and fulfilled life ${ }^{21}$. Untimely, excessive sleep or prolonged vigil is like the night of destruction that takes away happiness and longevity ${ }^{22}$. Sleep as Ratrisvabhava Prabhava (naturally occurring at night) is considered as healthy one $^{23}$. For healthy, natural sleep, the person should finish dinner at least 2 to 3 hours before the sleeping time; Cot should be adequate in size and height (approx at the level of person's knee joint), Bedding should be clean, soft and suitable in size. While going to bed one should remember only positive things of life and pray to the elders, teachers and almighty. Head should be directed to east or south direction ${ }^{24}$. One should lie on left lateral position $^{25}$ It is always better to avoid sleeping in day time, except in summer season due to the short period of night. Sleeping immediately after taking food and during the Sandhya Kala (dusk and dawn) is also unhealthy ${ }^{26}$. In general, for a healthy adult 6 to 8 hours quality sleep is enough. During different phases of our life the sleep requirement changes which are shown in table no. $2^{27}$ and Ayurvedic view on sleep pattern in different stages of life is shown in Table $3 .^{28}$

Table 2: Recommended amount of sleep in different stages of life

\begin{tabular}{|c|c|}
\hline Age & Recommended Amount of Sleep \\
\hline Newborn & $16-18$ hours a day \\
\hline Preschool-aged children & $11-12$ hours a day \\
\hline School-aged children & At least 10 hours a day \\
\hline Teens & $9-10$ hours a day \\
\hline Adults (including the elderly) & $7-8$ hours a day \\
\hline
\end{tabular}

Table 3: Ayurvedic view on sleep pattern in different stages of life

\begin{tabular}{|c|c|c|}
\hline Age & Dominance of Dosha & Sleep Pattern \\
\hline Balyavastha (Childhood) & Kapha & Ati-Nidrata (Excess sleep) \\
\hline Yuvavastha (Adulthood) & Pitta & Alpa-Nidrata (Less sleep) \\
\hline Vriddhavastha (Old age) & Vata & Nidranasha (Insomnia) \\
\hline
\end{tabular}

\section{Health risk burden due to sleep deprivation}

The public health burden due to chronic sleep loss and sleep disorders is an important matter of concern for health care system. It is estimated that 50 to 70 million Americans chronically suffer from a disorder of sleep and wakefulness, hindering daily functioning and adversely affecting health and longevity $^{29}$. More than one-quarter of the U.S. population reported occasionally not getting enough sleep, while nearly $10 \%$ experience chronic insomnia ${ }^{30}$. Many scientists believe that irregular sleeping patterns lead to illnesses ranging from aches and pains to heart diseases ${ }^{31}$. According to Harvard Medical School, sleeping less than five hours a night increases the hazard of dying from all causes by about 15 percent ${ }^{32}$.

\section{Psychiatric problem due to sleep deprivation}

For better knowledge and memory, good sleep is essential ${ }^{33}$. Sleep deprivation can be regarded as one among the reasons of anxiety disorders. Researches state that sleep disruptions can also be viewed in virtually all psychiatric complaints ${ }^{34}$. Studies show that the people who are doing the night shift duties are more prone to stress. Apart from this they will be having many related ailments like depression, heart disease, infertility, etc. The production of stress in our body is due to the action of various hormones. The human brain releases a hormone called $\mathrm{CRH}$. It will induce the pituitary gland to release ACTH. This in turn will cause the adrenal gland to produce epinephrine and other stress hormones leading to strain. Usually this chain is blocked by a good sleep. But when there is an alteration in the sleep habits, it can lead to an increased level of the stress hormones and thereby leading to stress ${ }^{35}$. An increase in stress can be noticed when the length and quality of sleep decreases ${ }^{36}$. It has been studied that sleep problems can precipitate manic and super manic episodes ${ }^{37}$. Excessive daytime sleepiness, depressed mood and poor memory or concentrations are the primary symptoms of sleep loss ${ }^{38}$. Adults with chronic sleep loss report excess mental distress, depressive symptoms, anxiety, and alcohol use ${ }^{39-41}$. It was found that insomnia is also a predictor of acute suicide among patients with mood disorders ${ }^{42}$. Restricted sleep time can negatively impact the behavioral alertness of a person ${ }^{43}$. Sleep deprivation negatively impacts our mood, our ability to focus, and our ability to access higher level cognitive functions which are generally referred to as mental performances $^{44}$.

\section{Neurological problem due to sleep deprivation}

Sleep deprivation is the cause for diseases due to vitiation of VataDosha ${ }^{45}$ which includes disorders related with neurology like Ardita (facial paralysis), EkangaRoga (monoplegia), SarvangaRoga (paraplegia) Pakshavadha (hemiplegia), Akshepaka (clonic convulsion),Dandaka (tonic convulsion) Bhrama (giddiness), Vepathu (tremors), Vishada (asthenia), Atipralapa (delirium), Atatvabhinivesha (unstable mentality) etc. Studies found that sleep impairment have association with dementia which include virilities of conditions like- Alzheimer's disease $^{46}$, Parkinson's disease ${ }^{47}$ etc. Sleep wake disturbances are found in at least 20 percent of stroke patients, ${ }^{48}$ which results in a sudden loss of consciousness, sensation, and voluntary 
movement caused by disruption of blood flow-and therefore oxygen supply - to the brain.Sleep problems can significantly reduce performance and alertness of a person ${ }^{49}$. People with insomnia feel more stressed out than people who have no trouble sleeping at night ${ }^{50}$. Sleep disturbances affect the functioning of the prefrontal cortex, the part of the brain, which is dealing with thinking, emotional regulation etc. ${ }^{51}$. Thus an impact of sleep loss on emotions can also be seen ${ }^{52}$. One recent study found that in mice $25 \%$ of certain brain cells died as a result of a prolonged lack of sleep ${ }^{53}$.

\section{Metabolic problem due to sleep deprivation}

In the Kaiyadeva Nighantu chapter on "Viharavarga" explains that staying awake at night specifically after $10 \mathrm{pm}$ which is considered as Pitta kala causes delayed digestion of consumed food and continuing being awake after $2 \mathrm{pm}$ which is considered as Vata Dosha dominant period completely disturbs the digestion process ${ }^{54}$. Sushrutacharya has described the untimely sleep pattern as an important cause of Ajirna (indigestion) ${ }^{55}$. In Modern science also sleep is found to have a strong relation with metabolism. The ghrelin also known as hunger hormone secreted by the stomach is having the function of appetite regulation. Leptin is a peptide secreted by adipose tissue, which has the satiety inducing function. These two help in maintaining a good appetite, metabolism, etc. Usually the leptin level increases during the daytime and has its peak during the night.
An irregular pattern during sleep can cause alteration in ghrelinleptin ratio. It can cause an increase in the level of ghrelin and decrease in leptin level. This can enhance the appetite and craving for especially carbohydrate rich foods. Studies have proved that higher BMI in children is associated with their short sleep ${ }^{56}$. According to some cross sectional epidemiological studies, both reduced and increased sleep duration is linked with hypertension, diabetes and obesity. Recent studies have suggested that there is a strong association between sleep disturbances and gastrointestinal diseases ${ }^{57}$. Persons with irritable bowel syndrome and "sensitive stomachs" experience an aggravation of their symptoms after a restless night. Stress which is produced due to sleep irregularity can exacerbate the digestive symptoms ${ }^{58}$. Sleep deprivation, specifically Insufficient SWS (small wave sleep), can cause impaired glucose tolerance. ${ }^{59}$ Studies have shown that people who reported sleeping less than five hours per night had a greatly increased risk of having or developing type 2 diabetes ${ }^{60}$.

\section{Consequences of sleep impairment}

Irregular sleep pattern vitiates all the three Dosha ${ }^{61-63}$ which become the cause of manifestation of various diseases. Here at the Table 4 the list of symptoms associated with an improper sleep pattern which are described in different classics of Ayurveda ${ }^{64-67}$. Table 5 shows the effect of Nidravegadharana (suppression of the natural urge to sleep) ${ }^{68-73}$.

Table 4: Symptoms produced due to inappropriate sleep

\begin{tabular}{|c|c|c|c|}
\hline Charaka Samhita & Astanga Samgraha & Sushruta Samhita & Astanga Hridaya \\
\hline Halimaka (Jaundice) & + & & + \\
\hline Sirasoola (Headache) & + & & \\
\hline Staimityam (Timidness) & + & + & + \\
\hline Guruta (Heaviness) & + & + & + \\
\hline Angamarda (Body aches) & + & & + \\
\hline Agni nasam (Loss of digestive fire) & + & + & + \\
\hline Hridayapralepa (Feeling of coating over heart) & + & & \\
\hline Sopha (Oedema) & + & & \\
\hline Arochaka (Anorexia) & + & & \\
\hline Hrillasa (Nausea) & + & & \\
\hline Peenasa (Rhinitis) & + & & \\
\hline Ardhavabhedaka (Hemicrania) & + & & \\
\hline Koda (Urticaria) & + & & \\
\hline Pidaka (Abscess) & + & & \\
\hline Kandu (Pruritis) & + & & \\
\hline Tandra (Drowsiness ) & + & & \\
\hline Kasa (Cough) & + & & \\
\hline Galamaya (Throat disease) & + & & \\
\hline Smriti (Memory loss) & + & & \\
\hline Srotorodha (Obstruction to channels) & + & & \\
\hline Jwara (Fever) & + & & \\
\hline Vishavegavardhanam (Increases the toxicity of poison) & + & & \\
\hline
\end{tabular}

Table 5: Effect of NidraVegadharana (Suppression of urge to sleep)

\begin{tabular}{|c|c|c|c|c|c|}
\hline Charaka Samhita & Sushruta Samhita & Astanga Hridaya & Astanga Samgraha & Bhavaprakasha & Yogaratnakara \\
\hline Jrimbha (Yawning) & + & + & + & + & + \\
\hline Angamarda (Body aches) & + & + & + & + & + \\
\hline Tandra (Stupor) & + & + & + & + \\
\hline Siroroga (Diseases of head) & + & + & + & + \\
\hline Sirogaurava (Heaviness of Head) & & + & & + \\
\hline Akshigaurava (Heaviness of eyes) & + & + & + & + \\
\hline Akshiroga (Diseases of eyes) & + & & + & + \\
\hline Tandra (Drowsiness) & & & + & + \\
\hline $\begin{array}{l}\text { Anannapaka } \\
\text { (Indigestion) }\end{array}$ & & & + \\
\hline
\end{tabular}




\section{CONCLUSION}

Sleep is an important physiological function of our body. Ayurveda regards Nidra as one of the most essential factors responsible for a healthy and satisfying lifetime. It is explained as one among the Trayopastambas i.e. the three great subsidiary pillars which support the life the others being Ahara and Brahmacharya. Any irregularities in these three can alter the homeostasis of the physical structure. Among these the Nidra (sleep) plays a vital role in maintaining health. The duals of life like Sukha (happiness), Dukha (miseries), Pushti (nourishment), Karshya (leanness) etc are dependent on proper and improper sleep. According to Ayurveda sleep occurring at night is to be viewed as normal while the remaining is abnormal and leads to unwanted health outcomes. Improper sleep is a condition which can affect the quality of life of a person. The concept of sleep is to be studied and explored well to maintain the health of a society.

\section{REFERENCES}

1. WHO technical meeting on sleep and health Available from http://www.euro.who.int/ data/assets/pdf file/0008/11410 1/E84683.pdf [assessed on 28 May 2016

2. Mei-Yen Chen, Edward $\mathrm{K}$ Wang and Yi-Jong Jeng, Adequate sleep among adolescents is positively associated with health status and health-related behaviours, BMC Public Health2006, 6:59.

3. Tiwari Mamta, Pandey Anurag, Chaudhari Poonam, Godatwar Pawankumar, Gupta Arvind Kumar. Ayurvedic approach for management of ageing and related disorder. Int. J. Res. Ayur. Pharm. 2013; 4(1):27-30 DOI: 10.7897/2277-4343.04117

4. Shepard JJW, Buysse DJ, Chesson JAL, Dement WC, Goldberg R, Guilleminault C, Harris CD, Iber C, Mignot E, Mitler MM, Moore KE, Phillips BA, Quan SF, Rosenberg RS, Roth T, Schmidt HS, Silber MS, Walsh JK, White DP. 2005. History of the development of sleep medicine in the United States. Journal of Clinical Sleep Medicine 1(1):6182.]

5. Jadavaji Trikamaji Acharya, Charaka Samhita of Agnivesha revised by Charaka and completed by Dridhabala, Reprint edition Varanasi: Chaukhamba Orientalia, 2007; Sutrasthana, Chapter 21, Verse 59 p.118

6. Your Guide to Healthy Sleep, NIH Publication No. 11-5271 Originally printed November 2005 Revised August 2011.U.S. Dept. of Health and Human Services, National Institute of Health

7. Jadavaji Trikamaji Acharya and Narayana Ram Acharya Kavyatirtha Sushruta Samhita of Sushruta, Reprint edition, Varanasi, Chaukhambha Surabharati Prakashana, 2008; Chikitsasthana, Chapter 24 Verse 88,p.- 491

8. Available from https://sleepfoundation.org/how-sleepworks/what-happens-when-you-sleep/page/0/1 on 14-6-16.

9. Available from, http://healthysleep.med.harvard.edu/needsleep/whats-in-it-for-you/health as assessed on 21-5-16

10. Jadavaji Trikamaji Acharya, Charaka Samhita of Agnivesha revised by Charaka and completed by Dridhabala, Sutrasthana Chapter, 21 Verse 35-48, Reprint edition Varanasi: Chaukhamba Orientalia, 2007; p.-118

11. Available from, http://healthysleep.med.harvard.edu/ healthy/matters/benefits-of-sleep as on 26-5-16

12. Jadavaji Trikamaji Acharya, Charaka Samhita of Agnivesha revised by Charaka and completed by Dridhabala, Reprint edition Varanasi: Chaukhamba Orientalia, 2007,Sutrasthana chapter 21, Verse 35-48 p-118
13. Available from https://www.nhlbi.nih.gov/files/docs/public/ sleep/healthy_sleep.pdf (Y O U R G U I D E T O Healthy Sleep) [as assessed on 16 Feb. 2016]

14. Jadavaji Trikamaji Acharya and Narayana Ram Acharya Kavyatirtha Sushruta Samhita of Sushruta, Reprint edition, Varanasi, Chaukhambha Surabharati Prakashana, 2008; Sharirasthana, Chapter 4, Verse 38-48p.- 359.

15. Lisa Gallicchio and Bindu Kalesan, Sleep duration and mortality: a systematic review and meta-analysis, J. Sleep Res. (2009) 18, 148-158

16. Jadavaji TrikamajiA charya, Charaka Samhita of Agnivesha revised by Charaka and completed by Dridhabala, Reprint edition Varanasi: Chaukhambha Orientalia, 2007; Sutrathana Chapter 21 Verse 36 p.-118

17. Shivprasad Sharma, Astanga Samgraha of Vagbhata, Reprint edition, Varanasi, Chaukhambha Sanskrita Bhavan, 2008; Sootra Sthana Chapter 9 Verse 31 p.- 92

18. Jadavaji Trikamaji Acharya and Narayana Ram Acharya Kavyatirtha Sushruta Samhita of Sushruta, , Reprint edition, Varanasi, Chaukhambha Surabharati Prakashana, 2008; Sareerasthana, Chapter 4 verse 40p.- 359

19. Bulusu Sitaram, Bhavaprakasha of Bhavamishra Vol. 1, Chaukhamba Orientalia, Reprint edition, Varanasi, Chaukhambha orientalia, 2015; Poorvakhanda, Chapter 5,Verse 300-301p.-95

20. Lakshmipati Shastri, Yogaratnakara with Vidyotini Hindi commentary edited by Brahmashankar Shastri, Reprint edition, Varanasi, Chaukhambha Prakashan, 2015,Chapter Nityapravrutiprakara Verse 48p.- 88

21. Shukla Akhilesh., D. Prasanth, Shukla Anupama., Baghel A. S. , Vyas M.K., Vellela J., Relevance of Sleep For Healthy Living - An Ayurvedic Perspective, Ayurveda Journal of Health, VOL. XII, ISSUE 3, SUMMER 2014; p. 27-34

22. Vaidya Harishastri Paradakara Bhishagacharya, Asthanga Hridayam of Vagbhata, Reprint edition, Varanasi, Chaukhamba Orientalia, 2005; Sutrasthana Chapter 7, Verse $61 \mathrm{p} .-142$.

23. Jadavaji Trikamaji Acharya, Charaka Samhita of Agnivesha revised by Charaka and completed by Dridhabala, Reprint edition, Varanasi; Chaukhamba Orientalia, 2007, Sutrasthana Chapter 21, Verse 51-59 p.-119.

24. Shivprasad Sharma Astanga samgraha of Vagbhata, Reprint edition, Varanasi, Chaukhamba Orientalia, 2012; Sutrasthana Chapter.3, Verse 46 p.- 25

25. Brahmasankara Misra, Bhavaprakasha of Bhavamishra, Reprint edition, Varanasi, Chaukhamba Orientalia, 2013, Poorvakhanda Verse 198p.-135

26. Brahmasankara Misra, Bhavaprakasha of Bhavamishra, Reprint edition,Varanasi, Chaukhamba Orientalia, 2013; Poorvakhanda Verse 275-276p.-144

27. Available from http://www.nhlbi.nih.gov/health/health topics/topics/sdd/howmuch.html [as assessed on 29 May 2016]

28. Bhishagacharya Harishastri Paradakara Vaidya, Asthanga Hridayam of Vagbhata, Chaukhamba Orientalia, Varanasi , 2005; Sutrasthana Chap.1, Ver. 8 p. -7.

29. NHLBI (National Heart, Lung, and Blood Institute) National Sleep Disorders Research Plan, 2003. Bethesda, MD: National Institutes of Health; 2003.

30. Available from http://www.cdc.gov/sleep/index.html [assessed on 28 May 2016]

31. Paul Ingraham, Vancouver, Canada Insomnia Until it Hurts May 32016 from https://www.painscience.com/ articles/insomnia-until-it-hurts.php [ as assessed on 14 June 2016]

32. Ann Pietrangelo The effects of sleep deprivation on the body August 19, 2014 Available from 
http://www.healthline.com/health/sleep-deprivation/effectson-body [ as assessed on 1 June 2016].

33. Jadavaji Trikamaji Acharya, Charaka Samhita of Agnivesha revised by Charaka and completed by Dridhabala, Reprint edition, Varanasi, Chaukhamba Orientalia, 2007; Sutrasthana Chapter 21, Verse 35-48 p.-118.

34. Waldemar Szelenberger And Constantin Soldatos Sleep disorders in psychiatric practice World Psychiatry. 2005 Oct; 4(3): 186-190. PMCID: PMC1414775

35. Kuem Sun Han, Lin Kim, and Insop Shim : Stress and Sleep Disorder Experimental Neurobiol. 2012 Dec; 21(4): 141150

36. Shelley D Hershner \& Ronald chervin, Causes and consequences of sleepiness among college students Nature and Science of Sleep. 2014; 6: 73-84.

37. ArgelindaBaroni, Jessica R. Lunsford, David A. Luckenbaugh, Kenneth E. Towbin, and Ellen Leibenluft ,Practitioner Review: The assessment of bipolar disorder in children and adolescents J Child Psychol Psychiatry 2009 March 50(3) 203- 215

38. Dinges D, Rogers N, Baynard, Chronic sleep deprivation. In: Kryger MH, Roth T, Dement WC, editors. Principles and Practice of Sleep Medicine. 4th ed. Philadelphia: Elsevier/ Saunders; 2005. pp. 67-76

39. Baldwin DC Jr, Daugherty SR. Sleep deprivation and fatigue in residency training: Results of a national survey of first- and second-year residents. Sleep. 2004;27(2):217-223

40. Hasler G, Buysse DJ, Gamma A, Ajdacic V, Eich D, Rossler $\mathrm{W}$, Angst J. Excessive daytime sleepiness in young adults: A 20-year prospective community study. Journal of Clinical Psychiatry. 2005;66(4):521-529.

41. Strine TW, Chapman DP. Associations of frequent sleep insufficiency with health-related quality of life and health behaviors. Sleep Medicine. 2005;6(1):23-27.

42. Fawcett J, Scheftner WA, Fogg L, Clark DC, Young MA, Hedeker D, Gibbons R. Time-related predictors of suicide in major affective disorder. American Journal of Psychiatry.1990;147(9):1189-1194.

43. Siobhan Banks and David F. Dinges, Behavioral and Physiological Consequences of Sleep Restriction Journal Of Clinical Sleep Medicine2007 Aug 15; 3(5): 519-528

44. Available from http://healthysleep.med.harvard.edu/ healthy/matters/consequences/sleep-and-disease-risk[as assessed on 1 June, 2016]

45. Jadavaji Trikamaji Acharya, Charaka Samhita of Agnivesha revised by Charaka and completed by Dridhabala, Reprint edition, Varanasi, Chaukhamba Orientalia, 2007; Chikitsasthana Chapter 28, Verse 17p.-617

46. Tractenberg RE, Singer CM, Kaye JA., Symptoms of sleep disturbance in persons with Alzheimer's disease and normal elderly. Journal of Sleep Research , 2005; 14(2):177-185.

47. Kales A, Ansel RD, Markham CH, Scharf MB, Tan TL, Sleep in patients with Parkinson's disease and normal subjects prior to and following levodopa administration. Clinical Pharmacology and Therapeutics, 1971;12(2):397406.

48. Bassetti CL., Sleep and stroke. In: Kryger MH, Roth T, Dement WC, eds. Principles and Practice of Sleep Medicine. 4th ed. Philadelphia: Elsevier/Saunders. 2005; p. 811-830.

49. Paula Alhola and Paivi Polo-Kantola, Sleep deprivation: Impact on cognitive performance Neuropsychiatric Disease and Treatment. 2007 Oct; 3(5): 553-567.

50. Ursula M. H. Klumpers, Dick J. Veltman, Marie-Jose van Tol, Reina W. Kloet, Ronald Boellaard, Adriaan A. Lammertsma, Witte J. G. Hoogendijk Neurophysiological Effects of Sleep Deprivation in Healthy Adults, a Pilot Study PLoS ONE 10(1): e0116906. Published: January 21, 2015 http://dx.doi.org/10.1371/journal.pone.0116906.
51. Namni Goel, Ph.D., Hengyi Rao, Ph.D., Jeffrey S. Durmer, M.D., Ph.D., and David F. Dinges, Ph.D. Neurocognitive Consequences of Sleep Deprivation Published in final edited form as: Semin Neurol. 2009 Sep; 29(4): 320-339. Published online 2009 Sep 9. doi: 10.1055/s-0029-1237117

52. Andrea N. Goldstein and Matthew P. Walker The Role of Sleep in Emotional Brain Function Annual Review of Clinical Psychology Vol. 10: 679-708 (Volume publication date March 2014) Published online 2014 Jan 31. doi: 10.1146/annurev-clinpsy-032813-153716

53. Viatcheslav Wlassoff, $\mathrm{PhD} \mid$ Lack of sleep affects performance and damages the brain cells May 28, 2014 from http://brainblogger.com/2014/05/28/lack-ofsleep-affects-performance-and-damages-brain-cells/ on 146-16.

54. Priyavrata Sharma and Guruprasad Sharma, Kaiyadev Nighantu (Pathyapathya-Vibodhaka), Reprint edition; Chaukhambha Orientalia, 2009; Viharavarga, Verse 377p.542.

55. Jadavaji Trikamaji Acharya and Narayana Ram Acharya Kavyatirtha Sushruta Samhita of Sushruta, Reprint edition, Varanasi, Chaukhambha Surabharati Prakashana, 2008; Sutrasthana, Chapter 46 Verse 500,p. 250-251.

56. The Link Between Sleep and Weight Gain - Research Shows Poor Sleep Quality Raises Obesity and Chronic Disease RiskBy Nancy L. Kondracki, MS, RD, LDN Today's Dietitian Vol. 14 No. 6 P. 48 on http://www.daysdietitian.com/newarchives/060112p48.shtm 1 [ as assessed on 26 May 2016]

57. Khanijow V, Prakash P, Emsellem HA, Borum ML, Doman DB Sleep Dysfunction and Gastrointestinal Diseases. Gastroenterol Hepatol (N Y). 2015 Dec; 11(12): 817-825. PMCID: PMC4849511

58. Tauseef Ali, James Choe, Ahmed Awab, Theodore L Wagener, and William C Orr, Sleep, immunity and inflammation in gastrointestinal disorders World $\mathrm{J}$ Gastroenterol. 2013 Dec 28; 19(48): 9231-9239. Published online 2013 Dec 28. doi: 10.3748/wjg.v19.i48.9231

59. The Link Between Sleep and Weight Gain - Research Shows Poor Sleep Quality Raises Obesity and Chronic Disease Risk By Nancy L. Kondracki, MS, RD, LDN $\begin{array}{llllll}\text { Today's Dietitian Vol. } 14 & \text { No. } 6 & \text { P. } 48\end{array}$ http://www.daysdietitian.com/newarchives/060112p48.shtm 1 [ as assessed on 26 May, 2016]

60. Available from http://healthysleep.med.harvard.edu/needsleep/whats-in-it-for-you/health [as assessed on 21 May, 2016]

61. Jadavaji Trikamaji Acharya and Narayana Ram Acharya Kavyatirtha Sushruta Samhita of Sushruta, Reprint edition, Varanasi, Chaukhambha Surabharati Prakashana, 2008; Chikitsasthana, Chapter 24 Verse 81-83p.- 490

62. Brahmashankara Mishra, Bhavaprakasha of Bhavamishra, Reprint edition, Chaukhambha Sanskrita Bhavan, 201; Poorvakhanda, Chapter 5, Verse 216, p.-. 137.

63. Jadavaji Trikamaji Acharya, Charaka Samhita of Agnivesha revised by Charaka and completed by Dridhabala, Reprint edition, Varanasi, Chaukhamba Orientalia, 2007; Chikitsasthana, Chapter 28, Verse 17,p.-617.

64. Jadavaji Trikamaji Acharya, Charaka Samhita of Agnivesha revised by Charaka and completed by Dridhabala, Reprint edition, Varanasi, Chaukhambha Orientalia, 2007; Sutrasthana Chapter 21 Verse 46-49p.- 118

65. Shivprasad Sharma, Astanga Samgraha of Vagbhata, Reprint edition, Varanasi, Chaukhambha Sanskrita Bhavan, 2007; Sutrathana, Chapter 9 Verse 39, p.- 92

66. Jadavaji Trikamji Acharya and Narayana Ram Acharya Kavyatirtha , Susruta Samhita of Sushruta, Reprint edition, 
Varanasi, Chaukhambha Surabharati Prakashana, 2008; Shareerasthana, Chapter 4 verse 38, p. 359

67. Vaidya Harishastri Paradakara Bhishagacharya, Asthanga Hridayam of Vagbhata, Sutrasthana Chapter 7 verse 61, Reprint edition, Varanasi, Chaukhamba Orientalia, 2012; p.142

68. Jadavaji Trikamaji Acharya, Charaka Samhita of Agnivesha revised by Charaka and completed by Dridhabala, Sutrasthana, Chapter 7 Verse 23, Reprint edition, Varanasi, Chaukhambha Orientalia, 2007; p.-50

69. Jadavaji Trikamaji Acharya and Narayana Ram Acharya Kavyatirtha , Susruta Samhita of Sushruta, Uttarasthana Chapter 55verse 17 , Reprint edition, Varanasi, Chaukhambha Surabharati Prakashana, 2008; p.-778.

70. Vaidya Harishastri Paradakara Bhishagacharya, Asthanga Hridayam of Vagbhata, Chaukhamba Orientalia, Varanasi Sutrasthana chapter 4 verse 12 pg 55.
71. Dr. Shivprasad Sharma, Astanga Samgraha of Vagbhata, Reprint edition, Varanasi, Chaukhambha Sanskrita Bhavan, 2012; Sutrasthana Chapter 5, Verse 12p. 32

72. Bulusu Sitaram, Bhavaprakasha of Bhavamishra, Vol.1, Reprint edition, Varanasi, Chaukhamba Orientalia, 2015; Poorvakhanda, Chapter 5,Verse 101p. - 76

73. Lakshmipati Shastri,Yogaratnakara with Vidyotini Hindi commentary edited by Brahmashankar Shastri, Reprint edition, Varanasi, Chaukhambha Prakashan, 2015; Chapter Nityapravrutiprakarah Verse 103p. 65

\section{Cite this article as:}

Suramya Suresh, Akhilesh Shukla, Haroon Irshad, Leena P Nair, Jaya Shankar Mund. Significance of natural sleep and effect of sleep deprivation on health: A review. Int. J. Res. Ayurveda Pharm. Jul - Aug 2016;7(Suppl 3):41-46 http://dx.doi.org/ $10.7897 / 2277-4343.074153$

Disclaimer: IJRAP is solely owned by Moksha Publishing House - A non-profit publishing house, dedicated to publish quality research, while every effort has been taken to verify the accuracy of the content published in our Journal. IJRAP cannot accept any responsibility or liability for the site content and articles published. The views expressed in articles by our contributing authors are not necessarily those of IJRAP editor or editorial board members. 